\title{
Recycling of the Proterozoic crystalline basement in the Coastal Block (Moroccan Meseta): New insights for understanding the geodynamic evolution of the northern peri-Gondwanan realm
}

\author{
Mohamed El Houicha $^{\mathrm{a}}$, Manuel Francisco Pereira ${ }^{\mathrm{b}, *}$, Abdellatif Jouhari ${ }^{\mathrm{a}}$, Cristina Gama ${ }^{\mathrm{b}}$, \\ Nasser Ennih $^{\mathrm{a}}$, Abdelilah Fekkak ${ }^{\mathrm{a}}$, Hassan Ezzouhairi ${ }^{\mathrm{a}}$, Ahmed El Attari ${ }^{\mathrm{a}}$, José Brandão Silva ${ }^{\mathrm{c}}$ \\ a Département de Géologie, Faculté des Sciences, Université Chouaib Doukkali, El Jadida, Morocco \\ ${ }^{\mathrm{b}}$ ICT-Departamento de Geociências, Escola de Ciências e Tecnologia, Universidade de Évora, Portugal \\ c IDL-Departamento de Geologia, Faculdade de Ciências da Universidade de Lisboa, Portugal
}

\section{A R T I C L E I N F O}

\section{Keywords:}

Detrital zircon age spectra

Provenance

Eburnian

Cadomian/Pan-African

North-Gondwana

Moroccan Meseta

\begin{abstract}
A B S T R A C T
Detrital zircon age spectra from the siliciclastic rocks of the Lalla Mouchaa Calcschists and El Jadida Dolomitic formations (the Coastal Block of the Moroccan Meseta) are dominated by Paleoproterozoic and Ediacaran ages. The provenance of these two formations is a composite Proterozoic crystalline basement. El Jadida rhyolite (584.2 $\pm 4.8 \mathrm{Ma}$ ) represents the Ediacaran crystalline basement of the El Jadida dome. El Jadida rhyolite is unconformably overlain by the microbreccia, arkosic sandstone and dolostone of the El Jadida Dolomitic Formation with a maximum depositional age of ca. 539 Ma (Lower Cambrian). Detrital zircon-age spectra from El Jadida Dolomitic Formation (ca. 583-582 Ma) suggest direct recycling of El Jadida rhyolite as an exclusive original primary source. However, in the Western Rehamna massif, detrital zircon-age spectra from pre-Middle Cambrian microbreccia and arkosic sandstone of the Lalla Mouchaa Calcschists Formation (ca. 2.05-2.03 Ga) indicate exclusive recycling of the ca. $2.05 \mathrm{Ga}$-aged crystalline basement rocks (original primary source). Detrital zircon contents of the siliciciclastic rocks from these two formations of the Coastal Block are consistent with derivation from either Eburnian (Paleoproterozoic) or Cadomian/Pan-African (Ediacaran) igneous rocks. The discovery of this composite Proterozoic crystalline basement in the Moroccan Meseta stresses that Cadomian/ Pan-African magmatic arcs were built on an Eburnian basement in a paleoposition close to the West African craton, as part of the northern peri-Gondwanan realm.
\end{abstract}

\section{Introduction}

Zircon U-Pb geochronology is frequently used to determine the age of both sedimentary sequences and crystalline basement rocks separated by unconformities with the aim of recognising and quantifying time gaps in the geologic record (Fedo et al., 2003; Mahon et al., 2014). It is also commonly used in provenance studies aimed at identifying the sources of strata deposited on top of unconformities (Gehrels et al., 2011; Thomas, 2011). Therefore, detrital zircon ages are of critical importance for creating a geological historical profile of sedimentary basins and their surrounding source regions (Fedo et al., 2003; Pereira et al., 2012a). However, provenance studies are not always based on the critical assumption that detrital zircon may be reworked through multiple sedimentary cycles, derived from the recycling of older sedimentary, igneous and metamorphic rocks and mixed with younger primary crystalline sources (Thomas, 2011;
Pereira et al., 2016a). Multi-cycle sedimentation is not always admitted as a possibility and in such cases misinterpretations may occur through the admission of the exclusivity of primary sources (Gehrels et al., 2011; Pereira et al., 2016b). By comparing them with crystallisation ages of potential source rocks, the identity of a provenance from detrital zircon-age spectra may be influenced by the dispersal path of sediment from the inferred provenance area to the depositional basin (Dickinson, 1988; Albardeiro et al., 2014). The mixing of detrital zircon from distinct sources is common when dispersal paths are complex and bring together a diverse assemblage of grains from multiple separate original primary and/or recycled secondary sources (Weltje and von Eynatten, 2004; Thomas, 2011; Pereira et al., 2016a,b). This kind of study has proved useful for providing stratigraphic correlations as well as the identification of sediment sources and/or transportation and depositional histories (Kosler and Sylvester, 2003).

\footnotetext{
* Corresponding author

E-mail address: mpereira@uevora.pt (M.F. Pereira).
} 